Behavioral/Cognitive

\title{
Paraventricular Thalamus Balances Danger and Reward
}

\author{
Eun A. Choi and $@$ Gavan P. McNally \\ School of Psychology, University of New South Wales, Sydney, New South Wales, 2052 Australia
}

\begin{abstract}
Foraging animals balance the need to seek food and energy against the accompanying dangers of injury and predation. To do so, they rely on learning systems encoding reward and danger. Whereas much is known about these separate learning systems, little is known about how they interact to shape and guide behavior. Here we show a key role for the rat paraventricular nucleus of the thalamus (PVT), a nucleus of the dorsal midline thalamus, in this interaction. First, we show behavioral competition between reward and danger: the opportunity to seek food reward negatively modulates expression of species-typical defensive behavior. Then, using a chemogenetic approach expressing the inhibitory hM4Di designer receptor exclusively activated by a designer drug in PVT neurons, we show that the PVT is central to this behavioral competition. Chemogenetic PVT silencing biases behavior toward either defense or reward depending on the experimental conditions, but does not consistently favor expression of one over the other. This bias could not be attributed to changes in fear memory retrieval, learned safety, or memory interference. Rather, our results demonstrate that the PVT is essential for balancing conflicting behavioral tendencies toward danger and reward, enabling adaptive responding under this basic selection pressure.
\end{abstract}

Key words: competition; danger; paraventricular thalamus; reward

\section{Significance Statement}

Among the most basic survival problems faced by animals is balancing the need to seek food and energy against the accompanying dangers of injury and predation. Although much is known about the brain mechanisms that underpin learning about reward and danger, little is known about how these interact to solve basic survival problems. Here we show competition between defensive (to avoid predatory detection) and approach (to obtain food) behavior. We show that the paraventricular thalamus, a nucleus of the dorsal midline thalamus, is integral to this behavioral competition. The paraventricular thalamus balances the competing behavioral demands of danger and reward, enabling adaptive responding under this selection pressure.

\section{Introduction}

Foraging animals balance the need to seek food and energy against the dangers of injury and predation. This is accomplished by multiple learning and memory systems that enable animals to predict and respond to sources of danger and reward in the environment. Much has been learned about the organization of these learning and memory systems. Learning to predict and respond to danger relies on amygdala, hippocampal, and prefrontal circuitries, among others, that encode fear associations (Maren and Quirk, 2004; Senn et al., 2014; Tovote et al., 2015) and interface with hypothalamic and brainstem circuitries for production of scalable defensive responses according to the imminence of danger (Fanselow and Lester, 1988;

Received Oct. 27, 2016; revised Jan. 31, 2017; accepted Feb. 3, 2017.

Author contributions: E.A.C. and G.P.M. designed research; E.A.C. performed research; E.A.C. and G.P.M. analyzed data; E.A.C. and G.P.M. wrote the paper.

This work was supported by Australian Research Council grants (DP130100310, DP160100004) and a Future Fellowship (FT120100250; to G.P.M.), as well as by an Australian Postgraduate Award (to E.A.C). We thank Rick Richardson, Fred Westbrook, Nathan Holmes, and Kathryn Baker for their helpful comments.

The authors declare no competing financial interests.

Correspondence should be addressed to Gavan P. McNally, School of Psychology, University of New South Wales, Sydney, NSW 2052 Australia. E-mail: g.menally@unsw.edu.au.

DOI:10.1523/JNEUROSCI.3320-16.2017

Copyright $\odot 2017$ the authors $\quad 0270-6474 / 17 / 373018-12 \$ 15.00 / 0$
Lee et al., 2014; Kunwar et al., 2015; Assareh et al., 2016; Tovote et al., 2016). Learning to predict and approach rewards depends on amygdala, prefrontal, and dorsal striatal circuitries that encode and store reward associations (Gallagher and Holland, 1994; Roesch et al., 2012), interfacing with ventral striatal, hypothalamic, and brainstem circuitries for generation of approach and ingestive behaviors (Kelley, 1999; Kelley et al., 2005; Petrovich et al., 2005).

In contrast, less is known about how these learning systems interact to accomplish basic survival needs. These neural systems are often segregated (but see Matsumoto and Hikosaka, 2009) so that separate populations of neurons in several brain regions (e.g., basolateral amygdala, ventral tegmental area) are excited by rewarding versus dangerous events (Lammel et al., 2012; Gore et al., 2015), and these separate populations are often located in different input-output circuitries (Lammel et al., 2012; Namburi et al., 2015). The paraventricular thalamus (PVT), located in the dorsal midline thalamus, is one candidate locus for interactions between reward and danger. The PVT receives inputs from brainstem and hypothalamic regions conveying energy balance and motivational states, and, in turn, projects to amygdala, prefrontal, and striatal regions important for reward and fear learning (Groenewegen and Berendse, 1994; Parsons et al., 2007; Li and 
Kirouac, 2012; Colavito et al., 2015; Kirouac, 2015). This diverse connectivity underpins PVT contributions to various aspects of learning and motivation (Kirouac, 2015), including circadian rhythms (Colavito et al., 2015), drug reward and withdrawal (Neumann et al., 2016; Zhu et al., 2016), reinstatement of drug seeking (Hamlin et al., 2009; James et al., 2010; James and Dayas, 2013), Pavlovian appetitive conditioning (Haight and Flagel, 2014; Haight et al., 2015), and fear-memory retrieval (PadillaCoreano et al., 2012; Do-Monte et al., 2015b; Dong et al., 2015).

Here we studied the role of the PVT in interactions between reward and danger. We used a behavioral task permitting concurrent assessment of defensive and reward approach behaviors to reveal competition between them. Then, using a chemogenetic approach (Urban and Roth, 2015), we examined the role of the PVT in these interactions as well as in other forms of motivational and memorial competition. Our results show that the PVT serves a critical role in balancing behavioral tendencies toward danger or reward without consistently favoring expression of one over the other.

\section{Materials and Methods}

Subjects. Subjects were 126 adult male Sprague Dawley rats, grouphoused in ventilated racks in a climate-controlled colony room on a 12:12 h light/dark cycle (lights on 7:00 A.M.). Experiments were conducted during the light cycle. All procedures were approved by the University of New South Wales Animal Care and Ethics Committee. Unless otherwise noted, rats were on a schedule of daily access to $12-18 \mathrm{~g}$ of standard chow commencing $3 \mathrm{~d}$ before the start of any behavioral procedures.

Apparatus. Standard operant chambers $[24$ (length) $\times 30$ (width) $\times$ $21 \mathrm{~cm}$ (height); Med Associates] were used. A recessed magazine $(5 \times 5$ $\mathrm{cm}$ ) in one wall of the chamber was attached to a pellet delivery system that delivered $45 \mathrm{mg}$ of grain pellets and a retractable lever was placed 4 $\mathrm{cm}$ to its right. For Experiment 5, these chambers were divided in to two sets of four, each with distinct visual (houselight-on vs houselight-off), olfactory (no odor vs peppermint), and tactile (metal grid vs Perspex floor) properties. The conditioned stimulus (CS) was a $30 \mathrm{~s}, 85 \mathrm{~dB}$ (A scale), $1800 \mathrm{~Hz}$ tone (0.1 s rise and fall) in Experiments 1, 2, and 4. In Experiment 3, the auditory fear conditioning to a tone CS (CSA) was a $20 \mathrm{~s}, 82 \mathrm{~dB}$ (A scale), $750 \mathrm{~Hz}$ tone and the fear conditioning to a different auditory CS (clicker; CSB) was an $82 \mathrm{~dB}, 10 \mathrm{~Hz}$ clicker. In Experiment 5, the CS was $20 \mathrm{~s}, 82 \mathrm{~dB}$ (A scale), $750 \mathrm{~Hz}$ tone. The foot shock stimulus (US) was a $0.5 \mathrm{~s}, 0.55 \mathrm{~mA}$ (Experiments 1, 2, and 4) or $0.7 \mathrm{~mA}$ (Experiments 3 and 5) scrambled shock delivered to the grid floor of each chamber. The shock was delivered during the last $0.5 \mathrm{~s}$ of the CS.

Viral vectors and clozapine-N-oxide injection. AAV5-CaMKII $\alpha$-HAhM4Di-IRES-mCitrine $\left[2 \times 10^{12}\right.$ viral particles per milliliter $\left.(\mathrm{vp} / \mathrm{ml})\right]$ and AAV5-CaMKII $\alpha$-enhanced yellow fluorescent protein (eYFP; $4 \times 10^{12} \mathrm{vp} /$ $\mathrm{ml}$ ) obtained from the University of North Carolina Vector Core (Chapel Hill, NC) were used. All rats were injected intraperitoneally with clozapine$\mathrm{N}$-oxide (CNO; $20 \mathrm{mg} / \mathrm{kg}$ in Experiment 1, 2 and 4; $15 \mathrm{mg} / \mathrm{kg}$ in Experiment 3 and 5; Mahler et al., 2014; Smith et al., 2016) 45 min before test. These doses of CNO were chosen based on past research and our immunohistochemical data showing that they yielded a $40-50 \%$ reduction in c-fos expression among designer receptor exclusively activated by a designer drug (DREADD)-expressing PVT neurons (see Fig. 7).

Surgery. Rats received intracranial stereotaxic surgery under ketamine $(100 \mathrm{mg} / \mathrm{ml})$-xylazine $(20 \mathrm{mg} / \mathrm{ml})$ anesthesia with $0.5 \%$ bupivacaine at the incision site and subcutaneous injection of carprofen $(5 \mathrm{mg} / \mathrm{kg})$. Once anesthetized, their heads were shaved and they were placed in a stereotaxic apparatus (Model 942, Kopf Instruments). The skull was exposed and a hand drill used to make two craniotomies above the PVT and $0.3 \mu \mathrm{l}$ of adeno-associated virus (AAV) vectors infused into PVT $[-2.6$ anteroposterior (AP), 0.1 mediolateral (ML), -6.0 dorsoventral (DV) and -3.6 AP, 0.1 ML, -6.1 DV in mm from bregma; Paxinos and Watson, 2007]. The infusion was made over a $3 \mathrm{~min}$ period at a rate of 0.1 $\mu \mathrm{l} / \mathrm{min}$ (UMP3 with SYS4 Micro-controller, World Precision Instru- ments). The syringe remained in place for 5-7 min. Immediately after surgery, rats were injected with procaine penicillin (Benicillin; Illium) and cephazolin sodium (Hospira). Daily postoperative and recovery procedures were conducted for the remainder of the experiment. Behavioral procedures commenced $\geq 3$ weeks later.

Behavioral procedures. In Experiment 1 (Fig. 1A), rats in Group Lever $(n=8)$ were trained to lever press for food pellets in $60 \mathrm{~min}$ sessions for $7 \mathrm{~d}$ before fear conditioning. Initially, they received a $45 \mathrm{mg}$ grain pellet for each lever press (Day 1 and 2 FR[Fixed Ratio]1), and thereafter on variable interval schedule (VI) 30 s (Day 3 ) then VI 60 s (Day 4 onwards). This VI 60 s remained in effect for Group Lever for the remainder of the experiment. Group None $(n=8)$ remained in their home cages during this lever training. On Day 1 of fear conditioning, after a $10 \mathrm{~min}$ baseline (BSL) period, both groups received five CS-alone presentations then seven CS-US pairings with a 3 min intertrial interval (ITI; Do-Monte et al., 2015b). Rats were returned to their home cages immediately after this session and remained there on Days 2 and 3. Rats were tested on Days 4 and 5 . These tests involved a 12 min BSL followed by four presentations of the tone CS at a 3 min ITI. Rats in Group Lever had access to the lever and magazine in all stages. Rats in Group None had access to the magazine only.

In Experiment 2 (Fig. $2 A$ ), the procedure was similar to that described for Group Lever in Experiment 1. Rats in Groups eYFP-Lever $(n=8)$, eYFP-Lever $+(n=7)$, hM4Di-Lever $(n=7)$, and hM4Di-Lever $+(n=$ 8) were trained to press a lever for food pellets as outlined in Experiment 1. On Day 1, rats received fear conditioning in a manner identical to that of Experiment 1. Rats were tested on Day 4 in a manner identical to that of Experiment 1. Rats in Group Lever remained undisturbed in their home cage on Days 2 and 3, whereas rats in Group Lever + were returned to the training context for 20 min on Days 2 and 3 and allowed to respond for food on the VI $60 \mathrm{~s}$ schedule. All groups had access to the lever and magazine at all stages in the context.

In Experiment 3 (Fig. 3A), on Stage I Day 1, rats in Group eYFP $(n=8)$ and Group hM4Di $(n=8)$, with ad libitum access to food in their home cages, were subjected to fear conditioning. After a $10 \mathrm{~min}$ BSL period, rats received three CSA-US pairings with a 3 min ITI. Rats were returned to their home cage immediately after this session and remained there undisturbed on Days 2 and 3. They were tested on Day 4. This involved a 12 min BSL period followed by four presentations of the tone CSA at a 2 min ITI. In Stage II, the same animals had access to $12-18 \mathrm{~g}$ of food per day in their home cages and were trained for $7 \mathrm{~d}$ to press a lever for food pellets in a different context using an FR1 schedule, then a VI $30 \mathrm{~s}$ schedule, and then a VI 60 s schedule, as described in Experiment 1. They then received fear conditioning of CSB on Day 1. Conditioning involved a 10 min BSL followed by three CSB-US pairings at a $3 \mathrm{~min}$ ITI. Rats were returned to their home cages immediately after this session. On Days 2 and 3 rats were returned to the training context for $20 \mathrm{~min}$ each day and allowed to respond for food on the VI $60 \mathrm{~s}$ schedule. On Day 4 rats were tested. This involved a $12 \mathrm{~min}$ BSL period followed by four presentations of CSB at a $2 \mathrm{~min}$ ITI. All groups had access to the lever and magazine in the context during all phases of Stage II.

In Experiment 4 (Fig. $4 A$ ), there were four groups: Group HungryeYFP $(n=8)$, Group Hungry-hM4Di $(n=8)$, Group Sated-eYFP $(n=$ $8)$, and Group Sated-hM4Di $(n=8)$. These groups varied according to the DREADD manipulation and the nature of the feeding schedule used. Rats in the Group Hungry-eYFP and Group Hungry-hM4Di received the same feeding schedule as used in Experiment 1 and this was in effect for the same duration before and during the fear conditioning, as in Experiment 1. Rats in Group Sated-eYFP and Group Sated-hM4Di were maintained on ad libitum access to food in their home cages throughout the experiment. There was no lever available in this experiment and there was no delivery of food pellets. The procedures for fear conditioning on Day 1 and for test on Day 4 were the same as Experiment 1. Rats remained undisturbed in their home cages on Days 2 and 3.

In Experiment 5 (Fig. $5 A$ ), two groups, eYFP $(n=8)$ and hM4Di $(n=8)$, were trained to lever press for food pellets in $60 \mathrm{~min}$ sessions for $9 \mathrm{~d}$ before test of $\mathrm{CNO}$ effects on appetitive behavior. Initially, rats received a $45 \mathrm{mg}$ grain pellet for each lever press (Day 1 and 2 FR1), and thereafter on an interval schedule of VI 30s (Day 3) then VI 60s (Day 4 
A

None

B

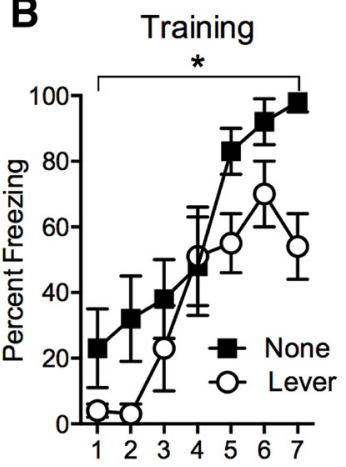

Lever
Training Day 1
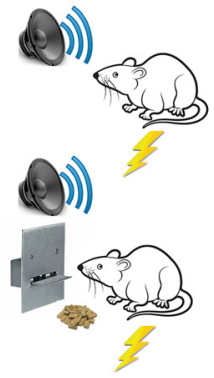

C

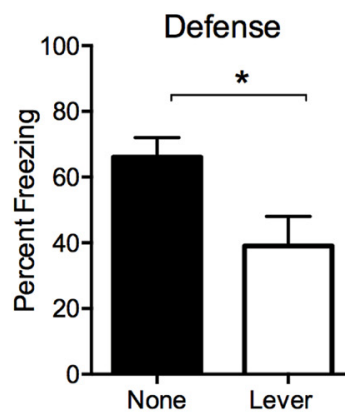

Days $2+3$

Test

Day 4

Homecage
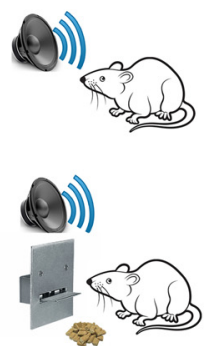

Homecage

D

Test

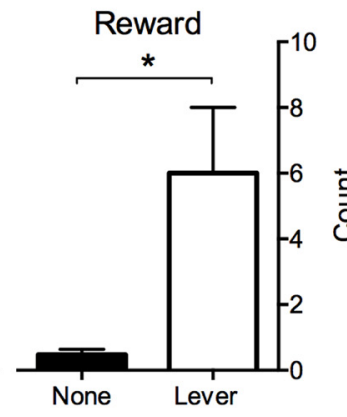

Group Lever

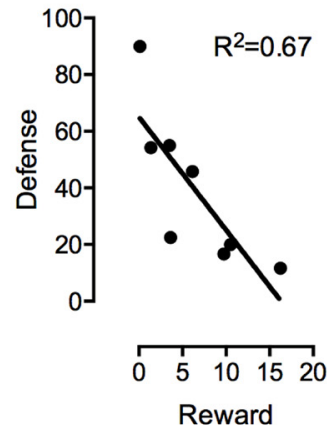

Figure 1. Competition between danger and reward. $A$, Design and procedure for None $(n=8)$ and Lever $(n=8)$ groups. B, Freezing behavior on the conditioning day for tone-shock pairings. $C$, Defense and reward behavior during tone presentations on the test day. Defense is percentage of observations where freezing was expressed. Reward is sum of approach behavior (lever press and food magazine entry). $\boldsymbol{D}$, Scatterplot of freezing and reward behavior for Group Lever during tone presentations on test day. Data are means \pm SEM. ${ }^{*} p<0.05$.

onwards). This VI 60 remained in effect for both groups for the remainder of the experiment. After the establishment of stable appetitive responses, rats were tested on Day 10, $45 \mathrm{~min}$ after injection of $20 \mathrm{mg} / \mathrm{kg}$ CNO. These tests involved a 26 min session with access to lever and magazine, which was the same duration as tests in the other experiments.

In Experiment 6 (Fig. 6A), two groups, eYFP $(n=8)$ and hM4Di $(n=8)$ with ad libitum access to food in their home cages, were subjected to an ABA fear renewal procedure (Bouton and Bolles, 1979). The procedure for conditioning was identical to Stage I of Experiment 3. Extinction involved 18 CS-alone presentations $20 \mathrm{~s}$ each, 3 min ITIs in a second, distinctive context. Rats were tested in the extinction $(\mathrm{ABB})$ and training context (ABA) on Days 3 and 4, 45 min after injection of CNO. These tests involved a 2 min BSL followed by four presentations of the $20 \mathrm{~s} \mathrm{CS}$ at $2 \mathrm{~min}$ ITI. There was no lever available at any stage.

Immunohistochemistry. For histological verification of DREADD expression, rats were anesthetized within 2 weeks of the end of behavioral training and fixed brains were extracted, postfixed, and cryoprotected in $20 \%$ sucrose $(24-48 \mathrm{~h})$. Brains were sectioned and stored in $0.1 \%$ sodium azide in $0.1 \mathrm{M}$ PBS, $\mathrm{pH}$ 7.2. An eGFP antibody was used to detect DREADD-expressing or eYFP-expressing cells. Sections were washed [0.1 м PB, pH 7.4, 50\% ethanol, $50 \%$ ethanol with $3 \%$ hydrogen peroxidase, and then 5\% normal horse serum (NHS) in PB for 30 min each], then incubated for 24-48 $\mathrm{h}$ in chicken antiserum against eGFP (1:2000; Life Technologies, catalog \#A10262) diluted in a PB containing $2 \%$ NHS and $0.2 \%$ Triton $\mathrm{X}-10$ in $0.1 \%$ sodium azide at room temperature. After washing in $\mathrm{PB}$, sections were incubated in biotinylated donkey antichicken (1:2000; Jackson ImmunoResearch Laboratories; $24 \mathrm{~h}$ at room temperature) diluted in a PB solution blocking buffer (2\% NHS and $0.2 \%$ Triton $\mathrm{X}-10$ in $\mathrm{PB})$. The sections were washed and incubated in avidin-biotinylated horseradish peroxidase complex (Vector Elite kit: 6 $\mu \mathrm{l} / \mathrm{ml}$ avidin and $6 \mu \mathrm{l} / \mathrm{ml}$ biotin; Vector Laboratories), diluted in $\mathrm{PB}$ containing $0.2 \%$ Triton $\mathrm{X}-10$ for $2 \mathrm{~h}$ at room temperature. Then, the sections were washed twice in $\mathrm{PB}$ and once in $0.1 \mathrm{M}$ acetate buffer, $\mathrm{pH}$ 6.0, and incubated (15 min) in a diaminobenzidine solution (DAB) contain- ing $0.1 \%$ 3,3-diaminobenzidine, $0.8 \%$ D-glucose and $0.016 \%$ ammonium chloride. Immunoreactivity (IR) was catalyzed by the addition of $0.2 \mu \mathrm{l} / \mathrm{ml}$ glucose oxidase ( $24 \mathrm{mg} / \mathrm{ml}, 307 \mathrm{U} / \mathrm{mg}$; Sigma-Aldrich).

For c-fos and eYFP immunohistochemistry, rats were anesthetized $2 \mathrm{~h}$ after injection of 15 or $20 \mathrm{mg} / \mathrm{kg}$ CNO. Two-color peroxidase immunohistochemistry was used to detect c-fos and eYFP IR. Sections were washed in $0.1 \mathrm{M} \mathrm{PB}, 50 \%$ ethanol, $50 \%$ ethanol with $3 \%$ hydrogen peroxidase, and then $5 \%$ NHS in PB as mentioned above and allowed for $48 \mathrm{~h}$ to incubate in rabbit anti-c-fos (1:2000; Santa Cruz Biotechnology, sc-52) and chicken antiserum against eGFP (1:2000; Invitrogen, A10262) diluted in a PB solution blocking buffer in $0.1 \%$ sodium azide for $48 \mathrm{~h}$ at room temperature. After washing in $\mathrm{PB}$, they were incubated in biotinylated donkey anti-rabbit (1:2000; Jackson ImmunoResearch Laboratories; $24 \mathrm{~h}$ at room temperature) diluted in $2 \% \mathrm{NHS}$ and $0.2 \%$ Triton X-10 in $\mathrm{PB}$ for $\mathrm{c}-$ fos IR. The sections were then washed in $\mathrm{PB}$ and incubated in $\mathrm{ABC}$ solution. Then, the sections were washed in $\mathrm{PB}$ and once in $0.1 \mathrm{M}$ acetate buffer, $\mathrm{pH}$ 6.0, and then incubated (15 min) in a DAB solution containing nickel (II) sulfate hexahydrate (Sigma-Aldrich, N4882) for black color. IR was catalyzed by $0.2 \mu \mathrm{l} / \mathrm{ml}$ glucose oxidase. Then the reaction was stopped the reaction in acetate buffer and the sections were washed three times in PB. Then the sections were incubated in biotinylated donkey anti-chicken (1:2000; Jackson ImmunoResearch Laboratories; $24 \mathrm{~h}$ at room temperature) diluted in $2 \%$ NHS and $0.2 \%$ Triton X-10 in PB for eYFP IR. After washing twice in PB and once in acetate buffer, sections were incubated in DAB solution without nickel (II) sulfate hexahydrate for brown color. The reaction was catalyzed by adding $0.2 \mu \mathrm{l} / \mathrm{ml}$ glucose oxidase and stopped in acetate buffer. All brain sections were then washed in $\mathrm{PB}$ and mounted and coverslipped with Entellan. C-fos-IR and eYFP-IR were imaged at $20 \times$ using a transmitted light microscope (Olympus BX51) and counted using Photoshop (Adobe). Three sections from each brain were counted and the sections were located $-2.52,-3.0$, and -3.60 in $\mathrm{mm}$ from bregma.

Scoring and statistics. Rats were scored every $2 \mathrm{~s}$ as either freezing (defined as the absence of all movement other than that required for breathing) or not 
A

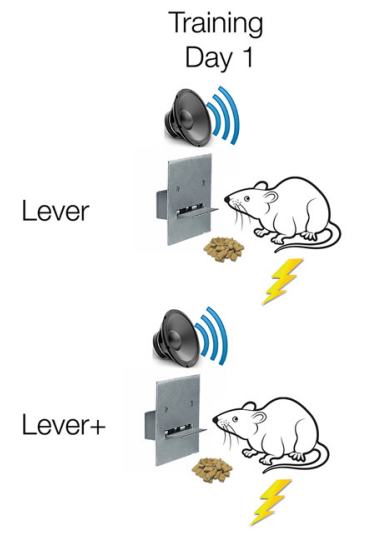

Days $2+3$

Homecage
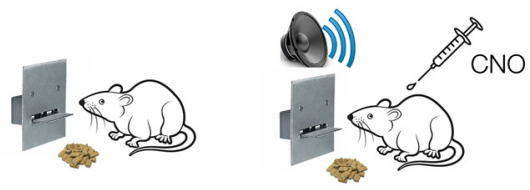

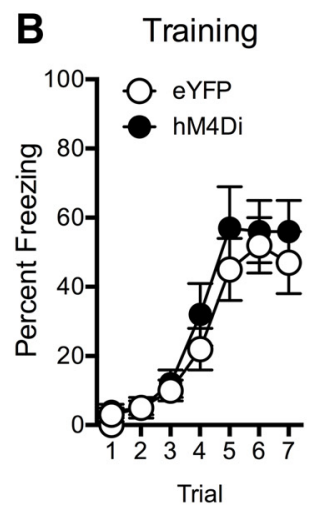

C Defense

Reward
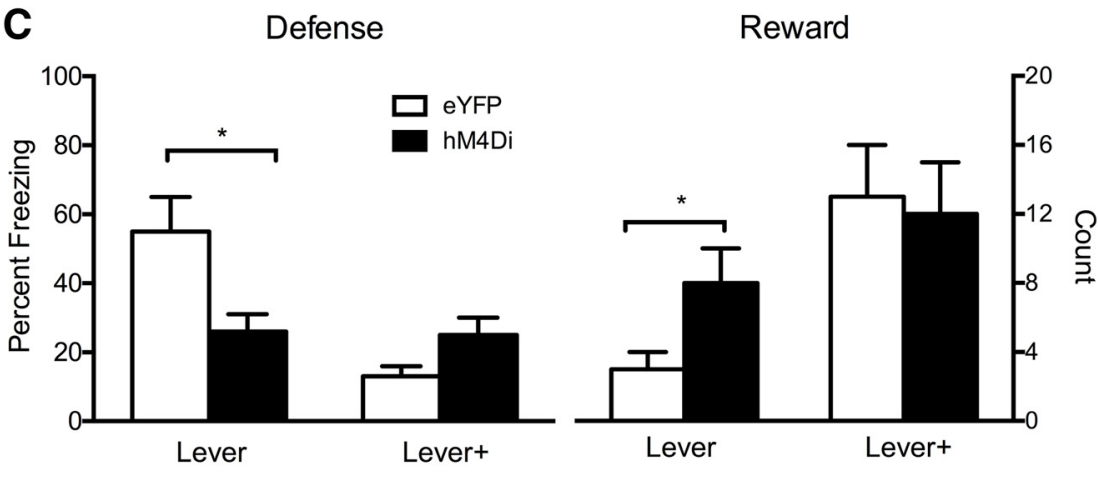

Figure 2. Effects of PVT silencing on competition between danger and reward. A, Design and procedure for Lever and Lever + groups. B, Freezing behavior on the conditioning day for tone-shock pairings. $C$, Defense and reward behavior during tone presentations on the test day. Defense is percentage of observations where freezing was expressed. Reward is sum of approach behavior (lever press and food magazine entry). Data are means \pm SEM. ${ }^{*} p<0.05$. Group sizes were as follows: eYFP-Lever, $n=8$; eYFP-Lever,$+ n=7 ;$ hM4Di-Lever, $n=7$; hM4Di-Lever,$+ n=8$.

freezing. The numbers of observations scored as freezing were summed and converted to a percentage. The number of lever presses and magazine entries were also recorded. These data were analyzed using a planned orthogonal contrast testing procedure and the type I error rate $(\alpha)$ was controlled at 0.05 for each contrast tested (Harris, 2004).

\section{Results}

Experiment 1: competition between danger and reward First we examined behavioral interactions between reward and danger. To do so we used a task that pitted expression of the species-specific defense response of "freezing" (a crouching, immobile posture that hinders detection of the rat by predators; Bolles and Fanselow, 1980; Fanselow and Lester, 1988) against approach behaviors to obtain a food reward. All rats received Pavlovian fear conditioning involving pairings of an auditory CS with foot shock (Fig. 1A). They were later tested for their defense reactions (freezing) to that CS. The groups differed, however, in the nature of their reward training. For Group None $(n=8)$, there was no reward training at any point in the experiment. For Group Lever $(n=8)$, both fear conditioning and testing occurred against a background of the opportunity to voluntarily lever press for a food reward. Presentations of the auditory fear CS on test should elicit the defensive response of freezing. The question was whether expression of defensive behavior was affected by the concurrent opportunity to respond for a food reward.

Freezing behavior during the training session is shown in Figure $1 B$. In all experiments, levels of freezing before tone CS presentations on conditioning and test did not differ between groups (Table 1). Freezing behavior was low initially but increased across conditioning trials as shown by a main effect of Trial $\left(F_{(1,14)}=\right.$
148.2, $p<0.05)$. There was a main effect of Group so that Group None showed more freezing behavior than Group Lever $\left(F_{(1,14)}=5.8, p<0.05\right)$, but there was no Group $\times$ Trial interaction so freezing behavior for both groups increased at the same rate $\left(F_{(1,14)}=1.6, p>0.05\right)$. Hence, concurrent reward approach interfered with the development of defensive behavior.

This interference was also observed when rats were tested $3 \mathrm{~d}$ later for fear responses to the auditory CS (Fig. 1C). Rats in Group None showed more freezing behavior to the CS than rats in Group Lever $\left(F_{(1,14)}=5.4, p<0.05\right)$. In contrast, as expected Group Lever showed more reward approach behavior during the CS (lever presses and entries to the magazine where food was delivered) than Group None $\left(F_{(1,14)}=10.2, p<0.05\right)$.

So, expression of a key species-specific defensive behavior was reduced by the concurrent opportunity to respond for a food reward. We further examined the relationship between defense and reward behaviors at the level of the individual animal for Group Lever (Fig. 1D). As expected, there was a negative correlation between these behaviors $\left(r=-0.82, R^{2}=0.67, p<\right.$ $0.05)$.

\section{Experiment 2: effects of PVT silencing on competition between danger and reward}

Next we asked whether PVT contributes to this competition between danger and reward. We used AAV vectors to express the inhibitory hM4Di DREADD (Rogan and Roth, 2011; Urban and Roth, 2015) or a control eYFP in PVT neurons and trained rats. For all groups, fear conditioning and testing occurred against a background of lever press responding for a food reward. The 
A

\section{Stage I}
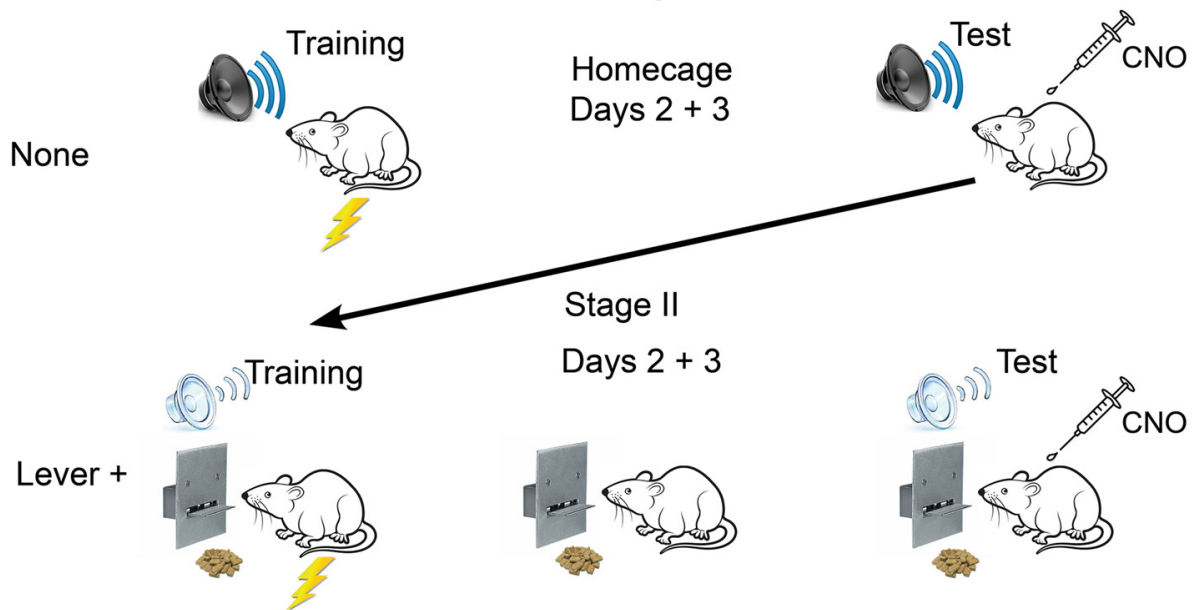

B

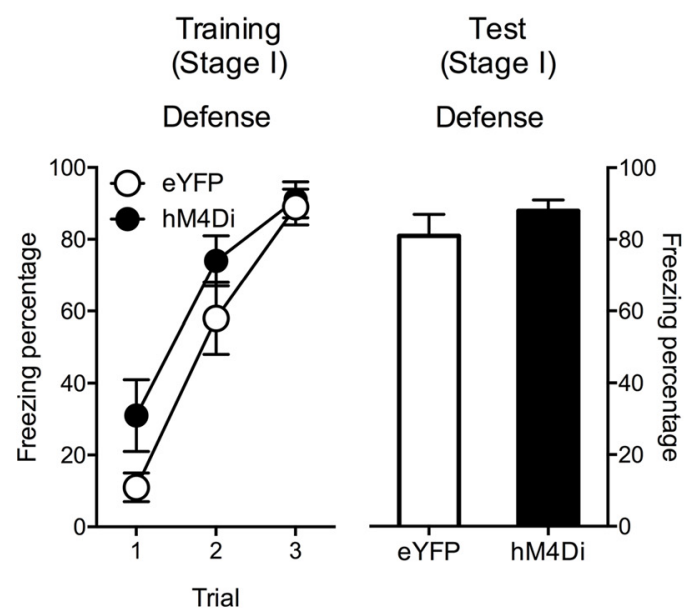

C

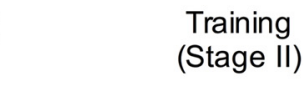

Defense

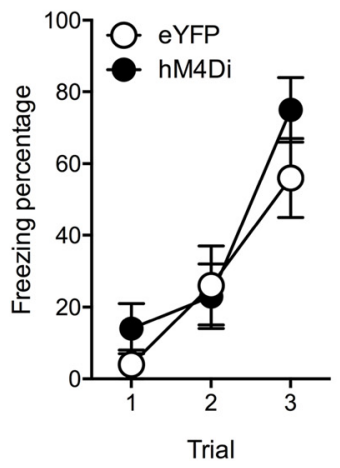

D Test

(Stage II)

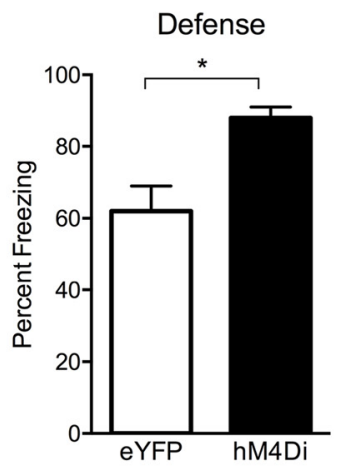

Reward

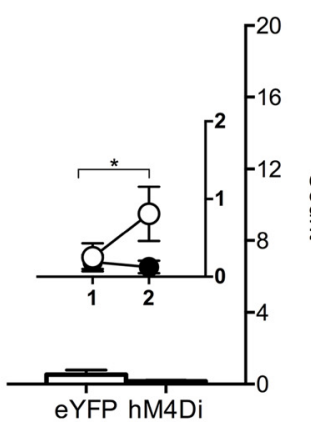

E

Test
(Stage I v Stage II)

Defense

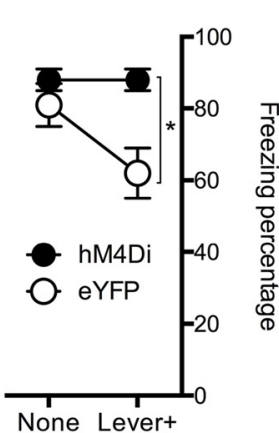

Figure 3. Effects of PVT silencing on danger in the absence and presence of reward. $A$, Design and procedure for the two stages. $B$, Freezing behavior on the conditioning day for tone-shock pairings and for tone presentations on test in Stage I. C, Freezing behavior on the conditioning day for each of the clicker-shock pairings in Stage II. D, Defense and reward behavior during clicker presentations on the test day. Defense is percentage of observations where freezing was expressed. Reward is sum of approach behavior (lever press and food magazine entry). Inset shows reward approach across blocks of two test trials. E, Comparison of freezing behavior during tone presentations on test in Stage l and Stage ll. Data are means \pm SEM. $p<<0.05$. Group sizes were as follows: $\mathrm{eYFP}, n=8 ; \mathrm{hM} 4 \mathrm{Di}, n=8$.

groups differed, however, in the relative strengths of reward training (Fig. 2A). All groups were treated the same as in Experiment 1 with one critical exception. Groups eYFP-Lever+ and hM4Di-Lever+ received additional lever-press training between fear conditioning and test. Our goal was to strengthen reward approach behavior to examine whether this caused additional disruption of defensive behavior. On test, we assessed defensive (freezing) and reward approach (lever presses and magazine entries) behavior during the auditory CS. All groups received an injection of the hM4Di ligand CNO before this test. Group sizes 
A

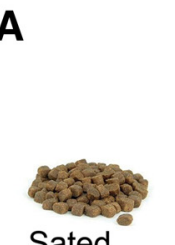

Training

Day 1
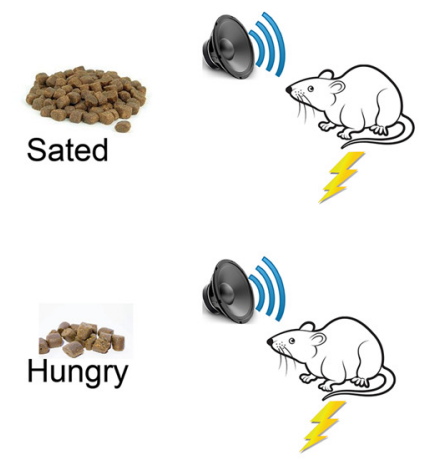

B

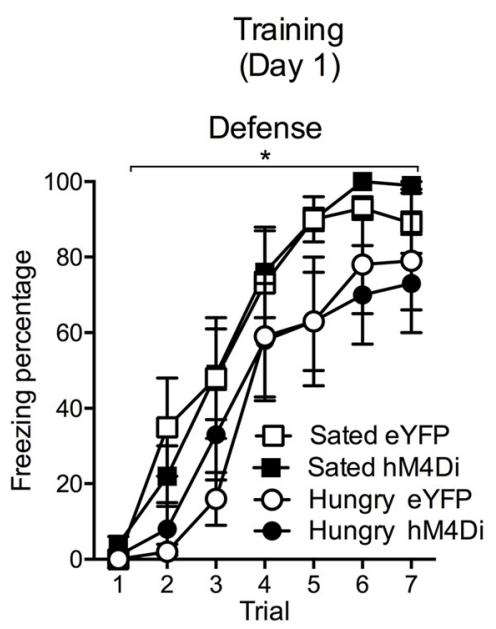

Training

Figure 4. Effects of PVT silencing on danger during hunger. $A$, Design and procedure for Hungry and Sated groups. $\boldsymbol{B}$, Defense is freezing behavior on the conditioning day for the tone-shock pairings and on test. Data are means $\pm S E M .{ }^{*} p<0.05$. Group sizes were as follows: eYFP-Hungry, $n=8$; eYFP-Sated, $n=8$; hM4Di-Hungry, $n=8$; hM4Di-Sated, $n=8$.

A

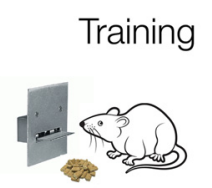

B

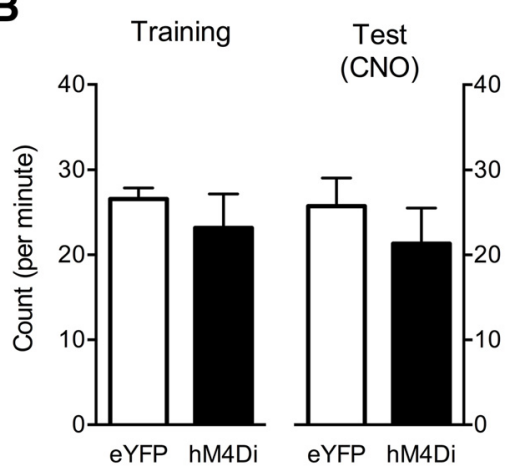

Figure 5. Effects of PVT silencing on instrumental responding for a food reward. $A$, Design and procedure. $\boldsymbol{B}$, Behavior (sum of lever press and food magazine entry) on the final training day and CNO test day. Data are means \pm SEM. Group sizes were as follows: eYFP, $n=8 ; \mathrm{hM} 4 \mathrm{Di}, n=8$.

were as follows: eYFP-Lever, $n=8$; eYFP-Lever,$+ n=7$; hM4DiLever, $n=7$; and group hM4Di-Lever,$+ n=8$ ).

Freezing behavior during fear conditioning is shown in Figure $2 B$. Data are collapsed across behavioral manipulation (Lever or

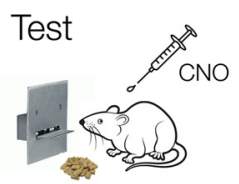

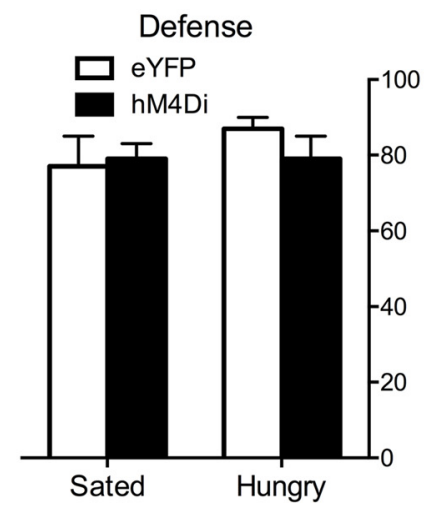

Test Day 4
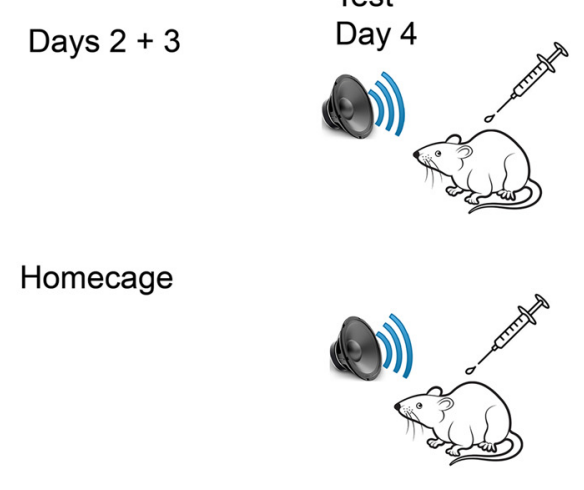

Test

(Day 4)

Homecage

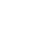
$<1, p>0.05)$, or any interactions $\left(F^{\prime} \mathrm{s}_{(1,26)}<1.3, p>0.05\right)$.

The primary data of interest are defense and reward approach behaviors on test (Fig. $2 C)$. Again, there was an antagonistic relationship between defense and reward approach but PVT silencing altered this. For freezing, Groups eYFP-Lever+ and hM4Di-Lever+ showed less defensive behavior than Groups eYFP-Lever and hM4Di-Lever $\left(F_{(1,26)}=8.9, p<0.05\right)$. Thus, as reward approach was strengthened, defensive behavior was further reduced. There was no main effect of DREADD $\left(F_{(1,26)}<1.6, p>0.05\right)$; chemogenetic silencing of PVT did not disrupt or augment overall levels of freezing. Importantly, there was an interaction between DREADD and behavioral training manipulation $\left(F_{(1,26)}=\right.$ 9.5, $p<0.05)$. Chemogenetic silencing of the PVT had opposite effects on defensive behavior in the two behavioral training conditions. Simple effect analyses showed for the Lever groups that chemogenetic silencing of PVT reduced freezing $\left(F_{(1,13)}=5.9\right.$, $p<0.05)$, whereas for the Lever+ groups, PVT silencing increased freezing but this was marginally short of statistical significance $\left(F_{(1,13)}=3.9, p=0.069\right)$.

For reward approach there was a main effect of behavioral training: Lever + groups showed more reward behavior than Lever groups $\left(F_{(1,26)}=9.9, p<0.05\right)$. There was no main effect of $\operatorname{DREADD}\left(F_{(1,26)}=1.0, p>0.05\right)$ and there was no interaction between the DREADD and behavioral training manipulations $\left(F_{(1,26)}=1.5, p>0.05\right)$. However, simple effect analyses showed that for Lever groups, chemogenetic silencing of PVT increased reward approach $\left(F_{(1,13)}=8.2, p<0.05\right)$, whereas for Lever+ groups, this silencing had no effect $\left(F_{(1,13)}<1, p>0.05\right)$.

\section{Experiment 3: effects of PVT silencing on danger in the} absence and presence of reward.

We show an antagonistic relationship between behavioral responses to danger and reward, and a role for the PVT in this behavioral competition. Here we sought to extend this. First, we included a control for the effects of PVT silencing on defensive behavior without competition from reward. Second, we used a different fear-conditioning protocol because the protocol we used in the previous experiments, although based on past research (Padilla-Coreano et al., 2012; Do-Monte et al., 2015a,b), supported low levels of freezing and these low levels of freezing hinder interpretation. This is important for interpretation of the effects of Lever+ training in Experiment 2, where additional training on lever pressing for food blunted the chemogenetic silencing effect so that the tendency to observe increased freezing during PVT silencing approached, but did not reach, statistical significance. Here we used a two-stage within-subject procedure 
to examine effects of PVT silencing on danger in the absence and presence of reward (Fig. 3A).

In Stage I (normal fear conditioning), Groups eYFP $(n=8)$ and hM4Di $(n=8)$ maintained on ad libitum access to food received CSA using parameters that yield high levels of defensive behavior (Monfils et al., 2009; Chan et al., 2010). Rats were then tested for their defensive responses to CSA. Next, in Stage II (fear conditioning and Lever+) rats were placed on a restricted feeding schedule and trained to lever press for food in a different context. They then received fear conditioning to a different auditory CS (clicker; CSB) superimposed on this lever-press task, followed by $2 \mathrm{~d}$ of lever-press training in the same context, before being tested for their fear responses to CSB. All groups received an injection of CNO before both tests.

There were two questions. Is the expression of defensive behavior negatively modulated by approach behavior to reward? If so, then animals should show less freezing on the Stage II test compared with the Stage I test. And, does the impact of PVT silencing depend on competition between defense and reward? If the impact of PVT silencing is independent of competition between defense and reward, then this silencing should affect fear in hM4Di animals on both tests. On the other hand, if the impact of PVT silencing depends on such competition, then based on the findings from Group Lever+ in Experiment 2, this silencing should affect fear in hM4Di animals during Stage II test only.

During Stage I training, freezing behavior increased across CS presentations $\left(F_{(1,14)}=148.1, p<0.05\right)$ and was the same across groups (Fig. $3 B)$. There was no main effect of DREADD $\left(F_{(1,14)}=\right.$ $2.4, p>0.05)$ or a DREADD $\times$ Trial interaction $\left(F_{(1,14)}=2.4\right.$, $p>0.05)$. On test, levels of CS-elicited freezing were high (Fig. $3 B)$ and there were no differences between groups $\left(F_{(1,14)}=1.2\right.$, $p>0.05)$. So, chemogenetic PVT silencing had no effect on defensive behavior in the absence of reward.

During Stage II training (Fig. 3C), freezing increased across CS presentations $\left(F_{(1,14)}=63.3, p<0.05\right)$ and again was the same across groups. There was no main effect of DREADD $\left(F_{(1,14)}<1\right.$, $p>0.05)$ or DREADD $\times$ Trial interaction $\left(F_{(1,14)}<1, p>0.05\right)$. On test (Fig. 3D), for freezing, there was an effect of DREADD $\left(F_{(1,14)}=12.7, p<0.05\right)$, showing that chemogenetic PVT silencing increased freezing. For reward approach, there were very low levels of lever pressing and magazine entries during CS presentations and the groups did not differ $\left(F_{(1,14)}=1.9, p>0.05\right)$. However, there was still an antagonistic relationship between defense and reward. In this experiment, this relationship was observed across the test trials (Fig. 3D, inset): Group eYFP showed more reward approach behaviors across the test CS presentations compared with Group hM4Di (Group $\times$ Trial interaction: $\left.F_{(1,14)}=5.1, p<0.05\right)$.

Next, to compare the effect of the presence versus absence of reward on expression of defensive behavior, we compared freezing behavior in the same animals between Stage I (no reward) and Stage II (rewarded lever pressing; Fig. 3E). We found less freezing in Stage II for the eYFP but not hM4Di group $($ DREADD $\times$ Stage interaction: $\left.F_{(1,14)}=7.8, p<0.05\right)$. So, defensive behavior was reduced by the opportunity to engage in reward approach and chemogenetic PVT silencing prevented this reduction.

\section{Experiment 4: effects of PVT silencing on danger during hunger}

In most of the tests reported here, rats were mildly hungry to encourage lever-pressing behavior. Given the extensive inputs to the PVT from hypothalamic neuropeptide populations implicated in energy balance and feeding ( $\mathrm{Li}$ and Kirouac, 2012; Colavito et al., 2015; Kirouac, 2015), it is possible that this feeding schedule, and the hunger it generated, was a determining factor in PVT balancing of danger versus reward (Padilla et al., 2016). To address this possibility, we examined the effect of food restriction on expression of defensive behavior and the effects of PVT silencing. Ad libitum feeding (Group Sated) or restricted feeding (Group Hungry) rats with eYFP or hM4Di expressed in the PVT received auditory Pavlovian fear conditioning and were later tested for their defensive responses to the CS (Fig. 4A). Four groups-Hungry-eYFP $(n=8)$, Hungry-hM4D $\mathrm{D}_{\mathrm{i}}(n=8)$, Sated$\operatorname{eYFP}(n=8)$, and Sated-hM4D $(n=8)$ - varied according to the DREADD manipulation and the nature of the feeding schedule used.

During training there was an increase in freezing behavior across trials (Fig. $\left.4 B ; F_{(1,28)}=235.2, p<0.05\right)$. Interestingly, sated rats expressed more fear $\left(F_{(1,28)}=11.0, p<0.05\right)$ than hungry rats. There was no difference between hM4Di and eYFP groups in overall levels of freezing behavior $\left(F_{(1,28)}<1, p>0.05\right)$ or the rate of freezing acquisition $\left(F_{(1,28)}<1, p>0.05\right)$ and no interaction between DREADD and food restriction $\left(F_{(1,28)}<1\right.$, 
Table 1. Mean and SEM levels of freezing behavior prior to CS presentations in each experiment

\begin{tabular}{|c|c|c|c|c|c|c|}
\hline Experiment & Group & Training & Test & Extinction & Test ABB & Test ABA \\
\hline \multirow[t]{2}{*}{ Experiment 1} & Lever & $0.4(0.4)$ & $1.0(0.4)$ & & & \\
\hline & None & $0.0(0.0)$ & $1.7(1.0)$ & & & \\
\hline \multirow[t]{4}{*}{ Experiment 2} & Lever-eYFP & $2.9(1.4)$ & $4.6(1.7)$ & & & \\
\hline & Lever-Hm4Di & $2.6(1.2)$ & $5.7(2.5)$ & & & \\
\hline & Lever+-eYFP & $0.2(0.2)$ & $0.0(0.0)$ & & & \\
\hline & Lever+-hM4Di & $0.8(0.4)$ & $1.7(1.0)$ & & & \\
\hline \multicolumn{7}{|l|}{ Experiment 3} \\
\hline \multirow[t]{2}{*}{ Stage I } & eYFP & $0.8(0.4)$ & $2.1(1.3)$ & & & \\
\hline & hM4Di & $3.1(1.8)$ & $6.3(2.9)$ & & & \\
\hline \multirow[t]{2}{*}{ Stage II } & eYFP & $1.0(0.0)$ & $1.5(1.5)$ & & & \\
\hline & hM4Di & $2.0(0.0)$ & $1.0(0.5)$ & & & \\
\hline \multirow[t]{4}{*}{ Experiment 4} & Sated-eYFP & $4.4(2.9)$ & $63.3(10.2)$ & & & \\
\hline & Sated-hM4Di & $1.3(0.8)$ & $53.5(13.0)$ & & & \\
\hline & Hungry-eYFP & $0.4(0.4)$ & $60.6(14.1)$ & & & \\
\hline & Hungry-hM4Di & $0.0(0.0)$ & $50.0(12.4)$ & & & \\
\hline \multirow[t]{2}{*}{ Experiment 5} & eYFP & $10.4(8.8)$ & & $1.3(0.9)$ & $11.3(5.1)$ & $2.9(0.8)$ \\
\hline & hM4Di & $4.4(3.1)$ & & $2.1(1.9)$ & $6.3(2.7)$ & $3.3(3.1)$ \\
\hline
\end{tabular}

$p>0.05$ ). On test (Fig. 4B), there were high levels of freezing behavior to the CS in all groups. There was no main effect of food restriction $\left(F_{(1,28)}>1, p>0.05\right)$, no main effect of DREADD $\left(F_{(1,28)}=1.3, p>0.05\right)$, and no DREADD $\times$ Food restriction interaction $\left(F_{(1,28)}=1.6, p>0.05\right)$. These findings demonstrate that without the opportunity to respond for food reward, neither food restriction nor chemogenetic silencing of PVT affect expression of defensive behavior.

Experiment 5: effects of PVT silencing on appetitive behavior These results show that PVT silencing shifts the balance between responding to reward and danger but has no effect on expression of defensive behavior in the absence of reward. It is possible, however, that chemogenetic inhibition of PVT simply alters responding for rewards. Although past research suggests that this is unlikely (Hamlin et al., 2009), this remains a possible explanation for the results observed here. For example, PVT silencing could alter retrieval of the action-outcome association, the incentive value of the reward, or the capacity to respond. To examine this possibility, we studied the effects of PVT chemogenetic silencing on instrumental responding in the absence of danger.

Two groups, eYFP $(n=8)$ and hM4Di $(n=8)$, were trained to respond on a lever for delivery of food reward (Fig. $5 A$ ). Then, on test, they received injection of CNO. Appetitive behavior (lever press and magazine entries) on the last day of training and on the $\mathrm{CNO}$ test are shown in Figure $5 B$. Appetitive behavior did not differ significantly across training and test, averaged across group (Training vs Test; no main effect of Session: $F_{(1,14)}=1.1, p>$ $0.05)$. Further, there was no difference between eYFP and hM4Di in overall levels of appetitive behavior when averaged across session (eYFP vs hM4Di; no main effect of Group: $F_{(1,14)}<1, p>$ $0.05)$, nor was there an interaction between these factors (Session $\times$ DREADD interaction: $\left.F_{(1,14)}=0.1, p>0.05\right)$. So, chemogenetic PVT silencing had no effect on appetitive behavior in the absence of competition from danger.

\section{Experiment 6: effects of PVT silencing on discrimination between safe and dangerous memories}

One interpretation of our results is that animals hold conflicting safe and dangerous memories. During reward training, rats learn that the context is safe and food available whereas during fear training they learn that this context is now dangerous. Moreover, in the Lever+ groups, there were additional exposures to the context in the absence of danger. Appropriate behavior requires, at least in part, discriminating and selecting between these conflicting memories. The PVT may be essential to this discrimination and selection.

To examine this possibility, we used a fear-renewal procedure (Bouton and Bolles, 1979). This procedure creates conflicting memories of danger and safety whereby rats explicitly use context as a guide to the danger posed by a CS (safe vs dangerous; Bouton, 1993; Fig. $6 B)$. Rats with eYFP $(n=8)$ or hM4Di $(n=8)$ expressed in the PVT received auditory fear conditioning in a distinctive context (A), before repeated presentations of the CS alone (extinction) in a different context (B). They were tested for fear responses to the auditory CS in the extinction (i.e., safe) and training (i.e., dangerous) context. Fear will be lower when tested in the extinction context $(\mathrm{ABB})$ than when tested in the training context (ABA). The question was as follows: does PVT chemogenetic silencing during test affect the balance between safety and danger?

Again, during training (Fig. 6C), freezing behavior increased across CS presentations $\left(F_{(1,14)}=115.5, p<0.05\right)$ but did not differ between groups (no main effect of DREADD, $F_{(1,14)}<1$, $p>0.05$; or DREADD $\times$ Trial interaction, $F_{(1,14)}=2.1, p>$ 0.05). During extinction, freezing behavior decreased across CS presentations $\left(F_{(1,14)}=33.8, p<0.05\right)$ and this did not differ between groups (no main effect of DREADD, $F_{(1,14)}<1$, $p>$ 0.05 ; or DREADD $\times$ Trial interaction, $\left.F_{(1,14)}<1, p>0.05\right)$. On test, as expected, there was more CS-elicited freezing behavior in the training context $(\mathrm{ABA})$ than the extinction context (ABB; $\left.F_{(1,14)}=18.1, p<0.05\right)$, showing the context-specificity of extinction and the ABA renewal of extinguished fear. Importantly, there were similar overall levels of CS-elicited fear behavior $\left(F_{(1,14)}<1, p>0.05\right)$ and ABA renewal (Context $\times$ DREADD interaction, $\left.F_{(1,14)}<1, p>0.05\right)$ in the eYFP and hM4Di groups. So, chemogenetic silencing of the PVT had no effect on retrieval or discrimination between safe and dangerous memories.

\section{Histology and DREADD validation}

Figure 7A)A-E shows the extent of eYFP and DREADD expression for all animals in all the experiments reported here, with each animal represented at 10\% opacity. In general, hM4Di expression was highest in the PVT with the occasional encroachment ventrally into intermediodorsal and central medial thalamic regions. However, even when expression did extend ventrally, expression 
A

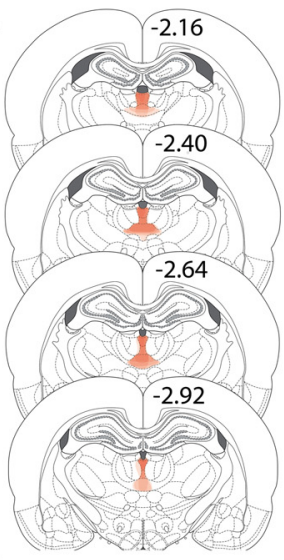

B

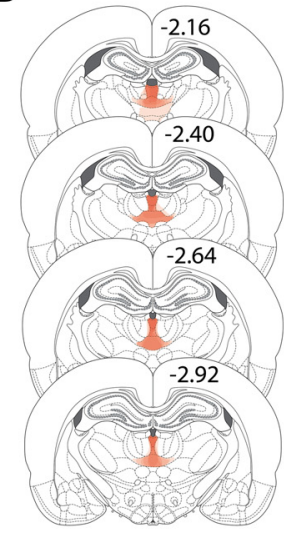

D

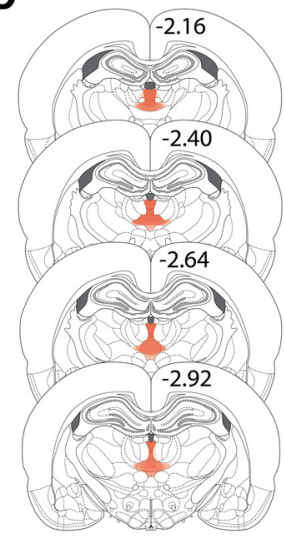

$\mathbf{F}$
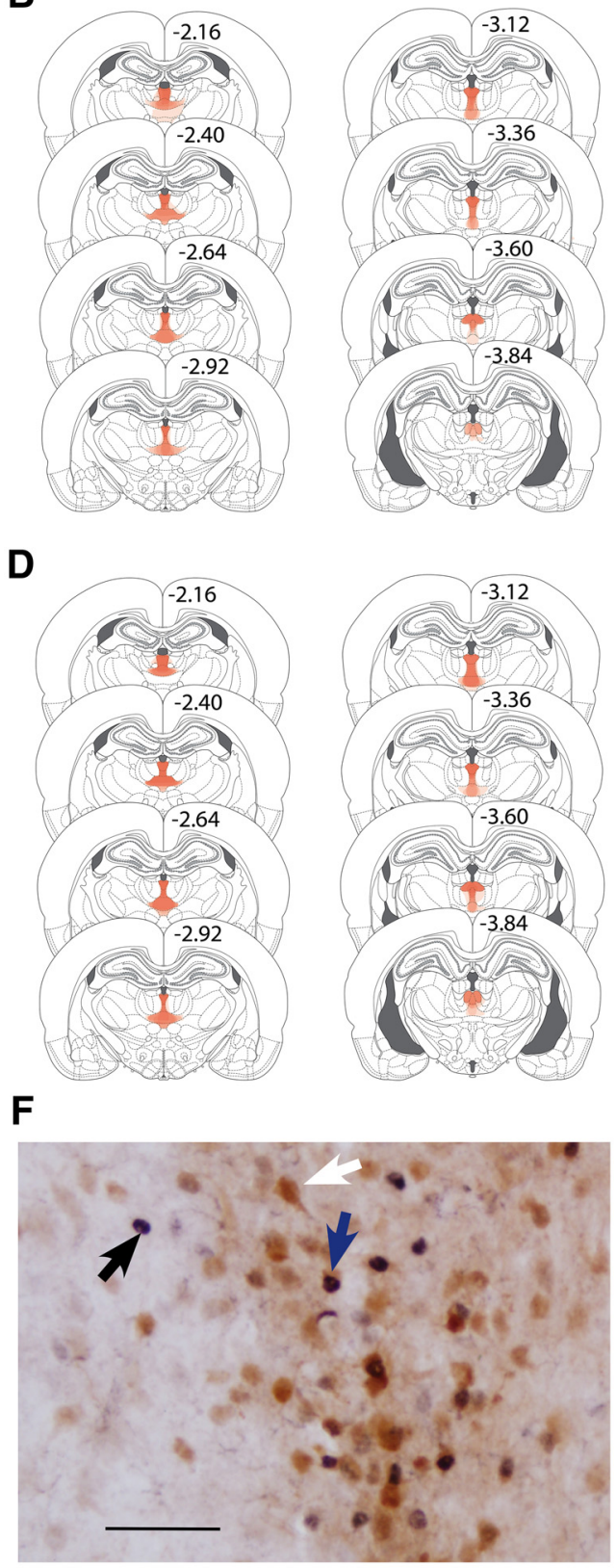

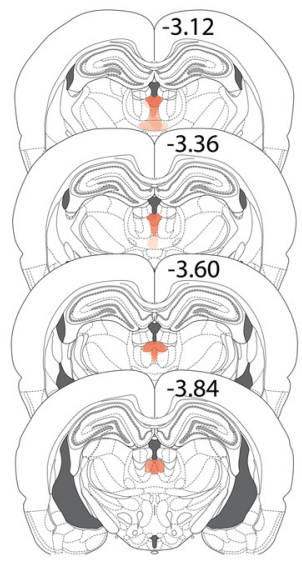

$\mathbf{G}$
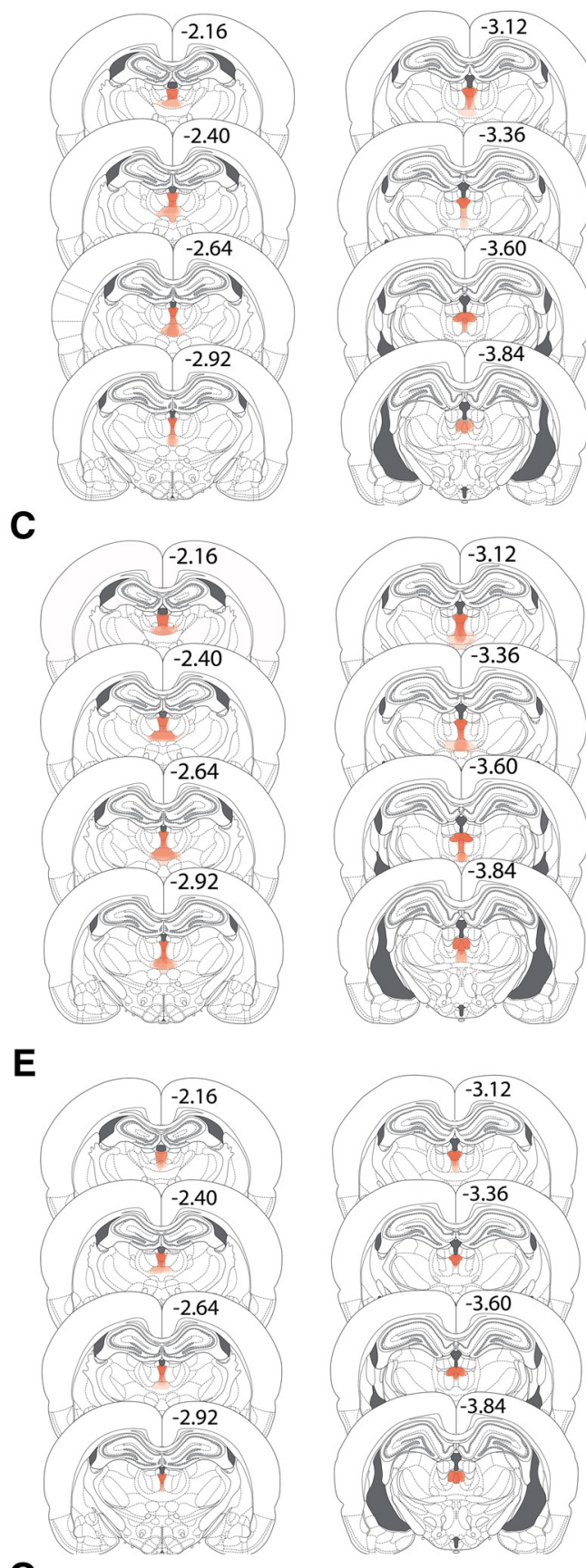

C
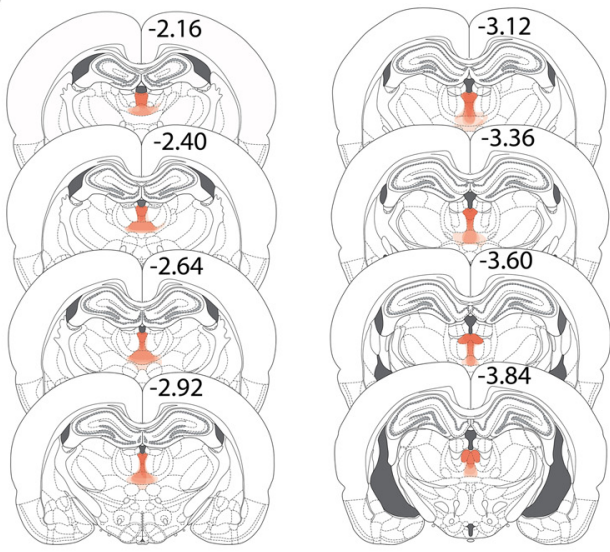

$\mathbf{E}$

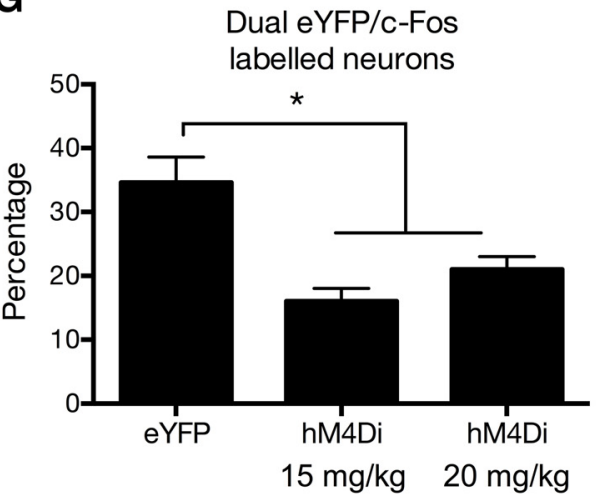

Figure 7. $A-E$, Location of hM4Di expression for all rats in Experiments $2(\boldsymbol{A}), 3(\boldsymbol{B}), 4(\boldsymbol{C}) 5(\boldsymbol{D})$, and $6(\boldsymbol{E})$ with the maximal extent of DREADD expression represented at $10 \%$ opacity for each rat. $\boldsymbol{F}$, Representative PVT section showing single-labeled c-fos (black arrow), single-labeled eYFP (white arrow), and dual-labeled eYFP/c-fos (blue arrow) neurons. Scale bar, $50 \mu \mathrm{m}$. G, Mean and SEM percentages of transduced neurons expressing c-fos for eYFP $(n=8), 15 \mathrm{mg} / \mathrm{kg}$ CNO-DREADD $(n=8)$, and $20 \mathrm{mg} / \mathrm{kg}$ CNO-DREADD $(n=8)$. * $p<0.05$. 
levels were always lower than observed in the PVT and DREADD expression did not encroach on the mediodorsal thalamus. No animals were excluded due to misplacements.

To confirm that CNO reduced activity of PVT neurons, we assessed c-fos expression in the PVT of hM4Di groups injected with $20(n=8)$ or $15(n=8) \mathrm{mg} / \mathrm{kg}$ CNO and Group eYFP injected with $15(n=4)$ or $20(n=4) \mathrm{mg} / \mathrm{kg} \mathrm{CNO}$ (Smith et al., 2016) and perfused $2 \mathrm{~h}$ later (Fig. $7 F, G$ ). There were no differences between groups in the numbers of transduced PVT neurons $\left(F_{(1,21)}<2.9>0.05\right)$ or in total number of c-fos-positive neurons $\left(F_{(1,21)}<1.5, p>0.05\right)$. However, there was a significant reduction in the number of dual eYFP/c-fos-positive neurons $\left(F_{(1,21)}=8.1, p<0.05\right)$, so that $\mathrm{CNO}$ reduced by $\sim 50 \%$ the number of PVT neurons expressing c-fos for DREADD animals compared with the eYFP controls, and there was no difference between the 15 and $20 \mathrm{mg} / \mathrm{kg}$ CNO dose $\left(F_{(1,21)}=3.0, p>0.05\right)$. Likewise, CNO significantly reduced the percentage of transduced neurons expressing $\mathrm{c}-f_{o s}\left(F_{(1,21)}=21.3, p<0.05\right)$ with no difference between the 15 and $20 \mathrm{mg} / \mathrm{kg}$ CNO dose $\left(F_{(1,21)}=2.3\right.$, $p>0.05)$. Hence, $\mathrm{CNO}$ at both doses used in these experiments significantly reduced activity, as indexed by expression of c-fos, of DREADD-expressing neurons.

\section{Discussion}

We studied behavioral interactions between reward and danger and the role of the PVT in these interactions. The major findings are that the opportunity to seek food reward negatively modulates expression of species-typical defensive behavior and that the PVT is central to this regulation. Chemogenetic PVT silencing biases behavior toward either defense or reward depending on the experimental conditions. This bias could not be attributed to changes in fear-memory retrieval, learned safety, or memory interference. Rather, our results demonstrate that the PVT balances the conflicting behavioral tendencies toward danger and reward, without consistently favoring expression of one over the other. In this way, the PVT may be crucial to solution of a basic survival problem.

Here the PVT served a modulatory role, balancing expression of defense and reward approach depending on the demands of the task. PVT silencing could decrease defense and increase reward approach or vice versa. The presence and recency of reward were factors determining PVT involvement and impact of PVT silencing. The PVT had no role in the absence of reward. When danger and reward were recently coexperienced, PVT silencing reduced defense and increased reward approach. However, when reward approach was more recently experienced than danger, PVT silencing increased defense and either had no effect or decreased reward approach. This role for the PVT was not simply due to hunger as PVT silencing had no effect on expression of defensive behavior in hungry or sated rats. This was not just due to the competing motoric or memorial demands of the tasks because PVT silencing had opposite effects on the same measures across experiments and did not alter the rat's ability to retrieve fear-extinction memories, to retrieve fear-conditioning memories, or to discriminate between extinction and training memories.

\section{Methodological considerations}

We used a chemogenetic approach to silence PVT neurons. The advantages of this approach to manipulating the PVT, compared with pharmacological approaches, are that we could identify the locus of our manipulation inside the midline thalamus and could independently verify its impact. To control for the expression of the hM4Di, as well as for any non-DREADD effects of CNO, we included eYFP-expressing control animals in each experiment (Yau and McNally, 2015; Sengupta et al., 2016). We were able to confirm that CNO injection in DREADD-expressing animals reduced activity in DREADD-expressing neurons. There was no evidence here that expressing the hM4Di in the PVT, or injection of $\mathrm{CNO}$, were themselves sufficient to alter defensive behavior because there was no effect of these manipulations across several experiments where we omitted behavioral competition between reward and danger. These findings argue against nonspecific effects of the DREADD or CNO here.

We expressed the hM4Di DREADD in the intermediate and posterior PVT (pPVT). There was minimal DREADD expression in the anterior PVT (aPVT). There are connectivity differences between the aPVT and pPVT, with the pPVT receiving the greater number of inputs from prelimbic, infralimbic, and posterior insular cortex and the aPVT the greater number of inputs from the subiculum (Li and Kirouac, 2012). Moreover, the pPVT projects extensively throughout the extended amygdala (Kirouac, 2015). So, the location of DREADD expression here was optimal for modulation of function involving these regions. Whether these differences in connectivity between the aPVT and pPVT map onto functional and behavioral differences is poorly understood and warrants empirical attention.

We pitted behavioral responses to a danger signal against lever pressing for food. We reasoned that this task best captures the conflict faced by the foraging animal between approach behavior to obtain food and defensive behavior to avoid predatory detection. There are other approaches to this issue. For example, it is possible to pit responding to two discrete cues predicting motivationally contrasted outcomes, such as food and shock (Nasser and McNally, 2012). The PVT is strongly recruited under such competition (Nasser and McNally, 2013), but its causal role in this behavioral competition is unknown.

\section{Dorsal midline thalamus: more than just memory retrieval?}

PVT chemogenetic silencing had no effect on defensive behavior in the absence of competition from reward and had no effect on reward behavior in the absence of competition from danger. PVT silencing was not sufficient to increase or decrease lever pressing or magazine entries when tested only for these behaviors and it was not sufficient to increase or decrease the defense response of freezing when tested only for defense, hungry or sated, when fear levels were low or high. Rather, the impact of PVT silencing depended specifically upon concurrent demands from the reward and danger tasks, and did not consistently favor expression of one behavior over the other.

These results may seem surprising given recent findings implicating the midline thalamus in retrieval of fear memories (Padilla-Coreano et al., 2012; Do-Monte et al., 2015b; Penzo et al., 2015). However, our finding is consistent with other recent work showing that selective PVT lesions do not affect fear expression in the absence of concurrent demand from a reward approach task (Li et al., 2014). In fact, there is broad agreement across these studies that manipulations of the PVT and adjacent midline regions, via lesions, reversible pharmacological inactivation, or chemogenetic silencing, can reduce expression of defensive behaviors, such as freezing, when animals have the concurrent opportunity to respond and approach for a food reward (Padilla-Coreano et al., 2012; Li et al., 2014; Do-Monte et al., 2015b). The important and novel findings here are that we show that this role for the PVT is only observed when there is competition between reward and danger and that PVT silencing can 
increase or decrease expression of defensive behavior depending on the conditions of competition.

Pharmacological inactivation of the entire dorsal midline thalamus can reduce expression of freezing in the absence of competition from reward (Do-Monte et al., 2015b). The dorsal midline thalamus is heterogeneous, comprising the PVT and the mediodorsal, intermediodorsal, and central medial thalamic nuclei. These nuclei have different connectivity and functions (Groenewegen and Berendse, 1994; Mitchell et al., 2014). Our DREADD expression was limited to the PVT with occasional but low levels of encroachment on other regions. In contrast, pharmacological inhibition of the PVT in past work affected the entire dorsal midline thalamus (Padilla-Coreano et al., 2012; Do-Monte et al., 2015b). These other nuclei have distinct roles in learning and memory. For example, the mediodorsal thalamic nucleus has a role in cognition and memory via its connectivity to the medial and lateral prefrontal cortex (Parnaudeau et al., 2013; Mitchell, 2015), which contributes to a time-dependent role in fearmemory retrieval (Li et al., 2004; Lee et al., 2011; Mátyás et al., 2014). In contrast, the central medial thalamus has a role in fear learning (Sengupta and McNally, 2014). These complementary roles for different dorsal midline thalamic regions in fear learning, memory, and motivation could account for the different findings of broad midline thalamic manipulations across studies. Regardless, they underscore the importance of the midline thalamus to adaptive behavior.

\section{A general role in motivational and response resolution?}

We show that the PVT is essential to balancing the competing behavioral demands of danger and reward. The conditions under which the PVT serves this role remain poorly understood. The relative recency of the competing behavioral demands may be important. When we manipulated the recency of reward training relative to fear conditioning, the behavioral impact of PVT silencing was reversed. This is strong evidence that the role of the PVT is to resolve the conflicting behavioral tendencies toward danger and reward, without consistently favoring expression of one over the other. Interestingly, there is evidence that the PVT may serve this function not just when behavioral competition is linked to opposing motivational states, such as danger and reward, but also when this competition occurs within a single motivational state. For example, Flagel and colleagues have shown that PVT lesions alter the balance between the opposing behavioral tendencies to approach a signal for reward versus approaching the reward itself in measures of sign and goal tracking (Haight and Flagel, 2014; Haight et al., 2015). PVT lesions attenuate the development of goal tracking and facilitated the development of sign tracking.

This role in balancing competing behavioral demands is likely linked to the PVT's location as an interface between viscerosensory hypothalamic and brainstem centers for feeding and energy balance, including hypothalamic peptidergic neurons (Kirouac et al., 2005, 2006), and limbic, striatal, and prefrontal circuits for emotion, response selection, and behavioral control (Su and Bentivoglio, 1990; Peng and Bentivoglio, 2004; Li and Kirouac, 2012; Colavito et al., 2015; Kirouac, 2015). Such connectivity enables the PVT to modulate behavior dependent on a variety of demands from both the internal (circadian, metabolic, nutritional) and external (threat salience, presence of food reward, presence of conspecifics) environments.

Competition between these demands is pervasive and solving this competition is fundamental to survival and daily function. However, there is rarely a stable, single solution. Rather, the appropriate solutions vary across different time scales (time of day, seasonal) as well as internal states (mood, arousal, sleep). In resolving this competition, the PVT may enable adaptive behavior under complex selection pressures.

\section{References}

Assareh N, Sarrami M, Carrive P, McNally GP (2016) The organization of defensive behavior elicited by optogenetic excitation of rat lateral or ventrolateral periaqueductal gray. Behav Neurosci 130:406-414. CrossRef Medline

Bolles RC, Fanselow MS (1980) A perceptual-defensive-recuperative model of fear and pain. Behav Brain Sci 3:291-323. CrossRef

Bouton ME (1993) Context, time, and memory retrieval in the interference paradigms of Pavlovian learning. Psychol Bull 114:80-99. CrossRef Medline

Bouton ME, Bolles RC (1979) Contextual control of the extinction of conditioned fear. Learn Motivation 10:445-466. CrossRef

Chan WY, Leung HT, Westbrook RF, McNally GP (2010) Effects of recent exposure to a conditioned stimulus on extinction of Pavlovian fear conditioning. Learn Mem 17:512-521. CrossRef Medline

Colavito V, Tesoriero C, Wirtu AT, Grassi-Zucconi G, Bentivoglio M (2015) Limbic thalamus and state-dependent behavior: the paraventricular nucleus of the thalamic midline as a node in circadian timing and sleep/ wake-regulatory networks. Neurosci Biobehav Rev 54:3-17. CrossRef Medline

Do-Monte FH, Manzano-Nieves G, Quiñones-Laracuente K, Ramos-Medina L, Quirk GJ (2015a) Revisiting the role of infralimbic cortex in fear extinction with optogenetics. J Neurosci 35:3607-3615. CrossRef Medline

Do-Monte FH, Quiñones-LaracuenteK, Quirk GJ (2015b) A temporal shift in the circuits mediating retrieval of fear memory. Nature 519:460-463. CrossRef Medline

Dong X, Li Y, Kirouac GJ (2015) Blocking of orexin receptors in the paraventricular nucleus of the thalamus has no effect on the expression of conditioned fear in rats. Front Behav Neurosci 9:161. CrossRef Medline

Fanselow MS, Lester LS (1988) A functional behavioralistic approach to aversive motivated behavior: predatory imminence as a determinant of the topography of defensive behavior. In: Evolution and learning (Bolles RC, Beecher MD, eds), pp 185-212. Hillsdale, NJ: Erlbaum.

Gallagher M, Holland PC (1994) The amygdala complex: multiple roles in associative learning and attention. Proc Natl Acad Sci U S A 91:1177111776. CrossRef Medline

Gore F, Schwartz EC, Brangers BC, Aladi S, Stujenske JM, Likhtik E, Russo MJ, Gordon JA, Salzman CD, Axel R (2015) Neural representations of unconditioned stimuli in basolateral amygdala mediate innate and learned responses. Cell 162:134-145. CrossRef Medline

Groenewegen HJ, Berendse HW (1994) The specificity of the "nonspecific" midline and intralaminar thalamic nuclei. Trends Neurosci 17:52-57. CrossRef Medline

Haight JL, Flagel SB (2014) A potential role for the paraventricular nucleus of the thalamus in mediating individual variation in Pavlovian conditioned responses. Front Behav Neurosci 8:79. CrossRef Medline

Haight JL, Fraser KM, Akil H, Flagel SB (2015) Lesions of the paraventricular nucleus of the thalamus differentially affect sign- and goal-tracking conditioned responses. Eur J Neurosci 42:2478-2488. CrossRef Medline

Hamlin AS, Clemens KJ, Choi EA, McNally GP (2009) Paraventricular thalamus mediates context-induced reinstatement (renewal) of extinguished reward seeking. Eur J Neurosci 29:802-812. CrossRef Medline

Harris RJ (2004) ANOVA: an analysis of variance primer. Itasca, IL: F.E. Peacock.

James MH, Dayas CV (2013) What about me ...? The PVT: a role for the paraventricular thalamus (PVT) in drug-seeking behavior. Front Behav Neurosci 7:18. CrossRef Medline

James MH, Charnley JL, Jones E, Levi EM, Yeoh JW, Flynn JR, Smith DW, Dayas CV (2010) Cocaine- and amphetamine-regulated transcript (CART) signaling within the paraventricular thalamus modulates cocaine-seeking behaviour. PLoS One 5:e12980. CrossRef Medline

Kelley AE (1999) Functional specificity of ventral striatal compartments in appetitive behaviors. Ann N Y Acad Sci 877:71-90. CrossRef Medline

Kelley AE, Baldo BA, Pratt WE (2005) A proposed hypothalamic-thalamicstriatal axis for the integration of energy balance, arousal, and food reward. J Comp Neurol 493:72-85. CrossRef Medline

Kirouac GJ (2015) Placing the paraventricular nucleus of the thalamus 
within the brain circuits that control behavior. Neurosci Biobehav Rev 56:315-329. CrossRef Medline

Kirouac GJ, Parsons MP, Li S (2005) Orexin (hypocretin) innervation of the paraventricular nucleus of the thalamus. Brain Res 1059:179-188. CrossRef Medline

Kirouac GJ, Parsons MP, Li S (2006) Innervation of the paraventricular nucleus of the thalamus from cocaine- and amphetamine-regulated transcript (CART) containing neurons of the hypothalamus. J Comp Neurol 497:155-165. CrossRef Medline

Kunwar PS, Zelikowsky M, Remedios R, Cai H, Yilmaz M, Meister M, Anderson DJ (2015) Ventromedial hypothalamic neurons control a defensive emotion state. Elife 4. CrossRef Medline

Lammel S, Lim BK, Ran C, Huang KW, Betley MJ, Tye KM, Deisseroth K, Malenka RC (2012) Input-specific control of reward and aversion in the ventral tegmental area. Nature 491:212-217. CrossRef Medline

Lee H, Kim DW, Remedios R, Anthony TE, Chang A, Madisen L, Zeng H, Anderson DJ (2014) Scalable control of mounting and attack by Esr1+ neurons in the ventromedial hypothalamus. Nature 509:627-632. CrossRef Medline

Lee S, Ahmed T, Lee S, Kim H, Choi S, Kim DS, Kim SJ, Cho J, Shin HS (2011) Bidirectional modulation of fear extinction by mediodorsal thalamic firing in mice. Nat Neurosci 15:308-314. CrossRef Medline

Li S, Kirouac GJ (2012) Sources of inputs to the anterior and posterior aspects of the paraventricular nucleus of the thalamus. Brain Struct Funct 217:257-273. CrossRef Medline

Li XB, Inoue T, Nakagawa S, Koyama T (2004) Effect of mediodorsal thalamic nucleus lesion on contextual fear conditioning in rats. Brain Res 1008:261-272. CrossRef Medline

Li Y, Dong X, Li S, Kirouac GJ (2014) Lesions of the posterior paraventricular nucleus of the thalamus attenuate fear expression. Front Behav Neurosci 8:94. CrossRef Medline

Mahler SV, Vazey EM, Beckley JT, Keistler CR, McGlinchey EM, Kaufling J, Wilson SP, Deisseroth K, Woodward JJ, Aston-Jones G (2014) Designer receptors show role for ventral pallidum input to ventral tegmental area in cocaine seeking. Nat Neurosci 17:577-585. CrossRef Medline

Maren S, Quirk GJ (2004) Neuronal signalling of fear memory. Nat Rev Neurosci 5:844-852. CrossRef Medline

Matsumoto M, Hikosaka O (2009) Representation of negative motivational value in the primate lateral habenula. Nat Neurosci 12:77-84. CrossRef Medline

Mátyás F, Lee J, Shin HS, Acsády L (2014) The fear circuit of the mouse forebrain: connections between the mediodorsal thalamus, frontal cortices and basolateral amygdala. Eur J Neurosci 39:1810-1823. CrossRef Medline

Mitchell AS (2015) The mediodorsal thalamus as a higher order thalamic relay nucleus important for learning and decision-making. Neurosci Biobehav Rev 54:76-88. CrossRef Medline

Mitchell AS, Sherman SM, Sommer MA, Mair RG, Vertes RP, Chudasama Y (2014) Advances in understanding mechanisms of thalamic relays in cognition and behavior. J Neurosci 34:15340-15346. CrossRef Medline

Monfils MH, Cowansage KK, Klann E, LeDoux JE (2009) Extinctionreconsolidation boundaries: key to persistent attenuation of fear memories. Science 324:951-955. CrossRef Medline

Namburi P, Beyeler A, Yorozu S, Calhoon GG, Halbert SA, Wichmann R, Holden SS, Mertens KL, Anahtar M, Felix-Ortiz AC, Wickersham IR, Gray JM, Tye KM (2015) A circuit mechanism for differentiating positive and negative associations. Nature 520:675-678. CrossRef Medline

Nasser HM, McNally GP (2012) Appetitive-aversive interactions in Pavlovian fear conditioning. Behav Neurosci 126:404-422. CrossRef Medline

Nasser HM, McNally GP (2013) Neural correlates of appetitive-aversive interactions in Pavlovian fear conditioning. Learn Mem 20:220-228. CrossRef Medline

Neumann PA, Yan Y, Wang Y, Ishikawa M, Cui R, Huang YH, Sesack SR, Schlüter OM, Dong Y (2016) Cocaine-induced synaptic alterations in thalamus to nucleus accumbens projection. Neuropsychopharmacology 41:2399-2410. CrossRef Medline
Padilla SL, Qiu J, Soden ME, Sanz E, Nestor CC, Barker FD, Quintana A, Zweifel LS, Rønnekleiv OK, Kelly MJ, Palmiter RD (2016) Agoutirelated peptide neural circuits mediate adaptive behaviors in the starved state. Nat Neurosci 19:734-741. CrossRef Medline

Padilla-Coreano N, Do-Monte FH, Quirk GJ (2012) A time-dependent role of midline thalamic nuclei in the retrieval of fear memory. Neuropharmacology 62:457-463. CrossRef Medline

Parnaudeau S, O'Neill PK, Bolkan SS, Ward RD, Abbas AI, Roth BL, Balsam PD, Gordon JA, Kellendonk C (2013) Inhibition of mediodorsal thalamus disrupts thalamofrontal connectivity and cognition. Neuron 77: 1151-1162. CrossRef Medline

Parsons MP, Li S, Kirouac GJ (2007) Functional and anatomical connection between the paraventricular nucleus of the thalamus and dopamine fibers of the nucleus accumbens. J Comp Neurol 500:1050-1063. CrossRef Medline

Paxinos G, Watson C (2007) The rat brain in stereotaxic coordinates, 6th Ed. Amsterdam: Elsevier.

Peng ZC, Bentivoglio M (2004) The thalamic paraventricular nucleus relays information from the suprachiasmatic nucleus to the amygdala: a combined anterograde and retrograde tracing study in the rat at the light and electron microscopic levels. J Neurocytol 33:101-116. CrossRef Medline

Penzo MA, Robert V, Tucciarone J, De Bundel D, Wang M, Van Aelst L, Darvas M, Parada LF, Palmiter RD, He M, Huang ZJ, Li B (2015) The paraventricular thalamus controls a central amygdala fear circuit. Nature 519:455-459. CrossRef Medline

Petrovich GD, Holland PC, Gallagher M (2005) Amygdalar and prefrontal pathways to the lateral hypothalamus are activated by a learned cue that stimulates eating. J Neurosci 25:8295-8302. CrossRef Medline

Roesch MR, Esber GR, Li J, Daw ND, Schoenbaum G (2012) Surprise! Neural correlates of Pearce-Hall and Rescorla-Wagner coexist within the brain. Eur J Neurosci 35:1190-1200. CrossRef Medline

Rogan SC, Roth BL (2011) Remote control of neuronal signaling. Pharmacol Rev 63:291-315. CrossRef Medline

Sengupta A, McNally GP (2014) A role for midline and intralaminar thalamus in the associative blocking of Pavlovian fear conditioning. Front Behav Neurosci 8:148. CrossRef Medline

Sengupta A, Winters B, Bagley EE, McNally GP (2016) Disrupted prediction error links excessive amygdala activation to excessive fear. J Neurosci 36:385-395. CrossRef Medline

Senn V, Wolff SB, Herry C, Grenier F, Ehrlich I, Gründemann J, Fadok JP, Müller C, Letzkus JJ, Lüthi A (2014) Long-range connectivity defines behavioral specificity of amygdala neurons. Neuron 81:428-437. CrossRef Medline

Smith KS, Bucci DJ, Luikart BW, Mahler SV (2016) DREADDS: use and application in behavioral neuroscience. Behav Neurosci 130:137-155. CrossRef Medline

Su HS, Bentivoglio M (1990) Thalamic midline cell populations projecting to the nucleus accumbens, amygdala, and hippocampus in the rat. J Comp Neurol 297:582-593. CrossRef Medline

Tovote P, Fadok JP, Lüthi A (2015) Neuronal circuits for fear and anxiety. Nat Rev Neurosci 16:317-331. CrossRef Medline

Tovote P, Esposito MS, Botta P, Chaudun F, Fadok JP, Markovic M, Wolff SB, Ramakrishnan C, Fenno L, Deisseroth K, Herry C, Arber S, Lüthi A (2016) Midbrain circuits for defensive behaviour. Nature 534:206-212. CrossRef Medline

Urban DJ, Roth BL (2015) DREADDs (designer receptors exclusively activated by designer drugs): chemogenetic tools with therapeutic utility. Annu Rev Pharmacol Toxicol 55:399-417. CrossRef Medline

Yau JO, McNally GP (2015) Pharmacogenetic excitation of dorsomedial prefrontal cortex restores fear prediction error. J Neurosci 35:74-83. CrossRef Medline

Zhu Y, Wienecke CF, Nachtrab G, Chen X (2016) A thalamic input to the nucleus accumbens mediates opiate dependence. Nature 530:219-222. CrossRef Medline 